A R C HIWA, BIBLIOTEKI

I MUZEA KOŚCIELNE 110 (2018)

https://doi.org/10.31743/abmk.2018.110.19

MARIAN SURDACKI* - LUBLIN

\title{
INFIRMERIA ŚWIĘTEGO DUCHA W RZYMIE W XVII-XVIII WIEKU. PERSPEKTYWY BADAWCZE
}

W historii rozwoju różnych form działalności i inicjatyw dobroczynno-charytatywnych, inspirowanych $\mathrm{w}$ decydujący sposób przez prawie osiemnaście stuleci, aż do oświecenia przez chrześcijańską doktrynę o miłosierdziu, fundamentalne znaczenie miał założony pod koniec XVIII w. w Prowansji przez Guidona z Montperllier szpitalny zakon Świętego Ducha (Ordo Fratrum Canonicorum Regularium Sancti Spiritus) Swoim szybkim rozwojem oraz skalą organizowanej pomocy i różnorodnością jej form zdecydowanie dominował w średniowieczu nad pozostałymi zgromadzeniami zakonnymi realizującymi podobną misję. Niekwestionowanym symbolem przodującej roli tego zakonu na polu dobroczynności w średniowiecznej Europie stał się Szpital Świętego Ducha in Saxia, ufundowany w 1198 r. w Rzymie, pozostający w zarządzie duchaków. Od początku szpital ten był najsławniejszą i największą placówką charytatywną w Europie, modelem dla prężnie rozwijających się w tym czasie szpitali, zarówno duchackich, jak i prowadzonych przez inne zgromadzenia zakonne, czy zakładanych przez instytucje świeckie i kościelne, np. bractwa, miasta, cechy ${ }^{1}$.

Monumentalny w rozmiarach budowli Szpital Świętego Ducha był domem macierzystym duchaków oraz siedzibą przełożonych generalnych zakonu. Aż do zjednoczenia Włoch w 1870 r. pozostawał pod protekcją papieża, w związku z czym nazywano go ,arcyszpitalem papieskim” (archiospedale apostolico). Po odbudowie w końcu XV w. i dalszych inwestycjach z XVI stulecia przeżywał okres największej swojej świetności. Pomimo radykalnych zmian związanych ze sposobem administrowania zachował, jako infirmeria, swoją rangę aż do czasów

* Marian Surdacki - prof. historii; kierownik Katedry Wychowania i Opieki Społecznej, Katolicki Uniwersytet Lubelski Jana Pawła II; e-mail: surdacki@kul.pl

ORCID 0000-0002-4649-8567

${ }^{1}$ M. Surdacki, Dzieci porzucone w Szpitalu Świętego Ducha w Rzymie w XVIII wieku, Lublin 1998, s. 5. 
obecnych, stanowiąc jedną z ważniejszych instytucji leczniczych dzisiejszego $\mathrm{Rzymu}^{2}$.

Od czasu dokonanej z polecenia papieża Sykstusa IV (1471-1483) rekonstrukcji, szpital aż do zjednoczenia Włoch pełnił dwie funkcje: przytułku dla podrzutków (brefotrofium) oraz szpitala-lecznicy dla chorych (infirmeria). Obie te instytucje, pod względem liczby podopiecznych (chorych i podrzutków) nie miały sobie równych na naszym kontynencie. W połowie XVIII w. w szpitalu było hospitalizowanych jednocześnie 957 chorych, zaś w ostatniej ćwierci XVIII w. szpital mógł pomieścić co najmniej 2.000 osób, w większości chorych. Odbudowa Szpitala Św. Ducha przez Sykstusa IV, zwanego drugim fundatorem, a następnie inwestycje z lat 1737-1749 oraz lat 70/80-tych XVIII w. nadały budowli ostateczny, zachowany do dzisiaj wygląd zewnętrzny. Był to kompleks w kształcie trójkąta, którego każdy bok miał długość $220 \mathrm{~m}$. Liczbą hospitalizowanych (jednorazowo - ok. 1.500) dorównywał największym współczesnym szpitalom - klinikom. Od 1870 r., wraz z przejęciem szpitala $\mathrm{w}$ administrację państwową i zaprzestaniem przyjmowaniu dzieci (kasata zakonu), specjalizował się on wyłącznie w leczeniu chorych. W czasach nowożytnych centralnym miejscem przebywania i leczenia chorych była wzniesiona z inicjatywy Sykstusa IV sala o wymiarach 125 m długości, 12 m szerokości i 14 m wysokości nazywana Corsia Sistina lub Sala Sistina. Przeznaczona była dla chorych mężczyzn. Chore kobiety umieszczano w odrębnym kompleksie budynków. O ile szpitale jako przytułki przechodziły wielowiekową ewolucję od funkcji socjalnej do funkcji medycznej, to Szpital Św. Ducha w Rzymie od początku pełnił funkcję medyczną ${ }^{3}$.

Funkcja opiekuńcza Szpitala Św. Ducha, jako przytułku dla dzieci porzuconych, została już kompleksowo zbadana i opracowana przez piszącego te słowa ${ }^{4}$.

${ }^{2}$ Tamże, s. 6.

${ }^{3}$ Tamże, s. 77-82.

${ }^{4}$ M. Surdacki, Dzieci porzucone w Szpitalu Świętego Ducha; tenże, Il brefotrofio dell'Ospedale di Santo Spirito in Roma nel XVIII secolo, Conferenze 115, Varsavia-Roma 2002; tenże, Dzieci porzucone w Rzymie i okolicach w XVIII wieku, „Roczniki Nauk Społecznych”, 22 (1994) z. 2, s. 84108; tenże, ,Figli legitimi” w Rzymie i Państwie Kościelnym w XVIII w. ,Roczniki Nauk Społecznych", 23 (1995) z. 2, s. 87-100; tenże, Losy wychowanków Szpitala Świętego Ducha w Rzymie w XVIII wieku, „Roczniki Nauk Społecznych”, 25 (1997) s. 141-168; tenże, Matżeństwa wychowanek Szpitala Świętego Ducha w Rzymie w XVII-XVIII wieku, „Kwartalnik Historii Kultury Materialnej”, 1996, nr 2, s. 137-156; tenże, Życie religijne podopiecznych Szpitala Świętego Ducha w Rzymie w XVII i XVIII wieku, „Roczniki Nauk Społecznych”, 24 (1996) z. 2, s. 315-333; tenże, Marriages of Wards of Rome's Holy Spirit Hospital in the $17^{\text {th }}$ and $18^{\text {th }}$ centuries, „Acta Poloniae Historica”, 79 (1999) s. 99-122; tenże, La vita religiosa nel „Conservatorio” dell'ospedale di Santo Spirito in Roma, nei secoli XVII-XVIII, „Ricerche di storia sociale e religiosa”, 27 (1998) nr 54, s. 149-165; tenże, L'abbandono dei bambini a Roma e dintorni nel secolo XVIII, „Archivio della Società romana di storia patria", 123 (2000) s. 169-199; tenże, I trovatelli nelle famiglie affidatarie a Roma e nei dintorni nel Settecento, „Ricerche di storia sociale e religiosa”, 30 (2001) nr 59, s. 91-120; tenże, Il "Conservatorio" e la "Scuola dei putti" nell'Ospedale di Santo Spirito di Roma nei secoli XVII-XVIII, Atti del convegno internazionale sull'antico ospedale di Santo Spirito di Roma, „Il Veletro. Rivista della Civiltà Italiana", 45 (2001) nr 5-6, s. 253-267; tenże, Le condizioni fisiche degli ospiti del brefotrofio di Santo Spirito in Roma nel XVIII secolo, „Medicina nei secoli”, 14 (2002) nr 1, s. 
Warto pokrótce przybliżyć czytelnikowi system opieki nad podrzutkami wypracowany w tej instytucji.

Budowa szpitala rzymskiego i jego struktura były tak zaplanowane, iż gwarantowały osobom podrzucającym swoje dzieci całkowitą anonimowość i dyskrecję. Przynoszone o zmroku lub w nocy dzieci zostawiano w drewnianym bębnie wmontowanym w mury zewnętrzne szpitala. Po obróceniu bębna, na sygnał dzwonka, podrzutki odbierała dyżurna czuwająca wewnątrz szpitala. Tuż po tym nacinano na prawej stopie dziecka znak podwójnego krzyża, stanowiący symbol szpitala i Zgromadzenia Świętego Ducha. Piętnowanie miało zapobiegać nadużyciom związanym $\mathrm{z}$ handlem podrzutkami i wykorzystywaniem ich do celów zarobkowych. Po nacięciu znaku krzyża podrzutki poddawano ceremonii chrztu, a następnie przekazywano je dyżurującym w szpitalu mamkom (balie di casa), których zadaniem było karmienie dzieci piersią. W XVIII w. do Szpitala Św. Ducha podrzucano corocznie blisko 1.000 dzieci $^{5}$.

Głównym źródłem rekrutacji podrzutków były miasteczka i miejscowości zlokalizowane z reguły w promieniu do $100 \mathrm{~km}$ od Rzymu. Zgodnie z pierwotną ideą Innocentego III szpital przeznaczony był dla dzieci nieślubnych, pochodzących z nielegalnych związków pozamałżeńskich. W praktyce, dużą część podrzutków szpitalnych stanowiły dzieci z pełnych rodzin. Do szpitala podrzucano najczęściej dzieci zaledwie kilkudniowe, lub nawet tuż po porodzie, o ile pochodziły z Rzymu. Po krótkim pobycie w brefotrofium, podrzutki powierzane były na wykarmienie i wychowanie kobietom mieszkającym poza szpitalem (balie di fuori). W zamian za opiekę nad dziećmi, mamki otrzymywały ze szpitala regularną comiesięczną pomoc finansową i ubrania. Większość dzieci oddawanych w opiekę do małych miasteczek i wsi trafiała do rodzin wieśniaczych, natomiast rodziny opiekujące się dziećmi szpitalnymi w Rzymie najczęściej trudniły się rzemiosłem ${ }^{6}$.

Dzieci wzięte ze szpitala na wykarmienie i wychowanie, po okresowym pobycie u swoich opiekunów, musiały być bezwarunkowo oddane $\mathrm{z}$ powrotem do przytułku. W przypadku dziewczynek ostateczny termin powrotu stanowiło ukończenie przez nie 11 lat, chłopcy natomiast mogli przebywać poza szpitalem o rok dłużej. Powracające od mamek dziewczęta lokowane były w przytułku żeńskim conservatorio, zaś podrzutki płci męskiej w szkole dla chłopców - scuola dei putti. Chłopcy po powrocie niezbyt długo przebywali w szpitalu. Stanowiąc tanią siłę roboczą, byli chętnie przyjmowani, szczególnie przez rzemieślników, na służbę, a zarazem na naukę zawodu. Po wyuczeniu się konkretnego rzemiosła z czasem usamodzielniali się, zakładali rodziny i prowadzili niezależne życie. Czasami, podobnie zresztą jak dziewczynki, trafiali $\mathrm{w}$ adopcję. W konsekwencji niewielu

111-134; tenże, Le nutrici a Roma e nello Stato pontificio nei secoli XVII-XVIII, „Archivio della Società romana di storia patria”, 125 (2002) s. 105-126; tenże, La scuola per i maschi nell'Ospedale di Santo Spirito di Roma nei secoli XVII-XVIII., „Studium”, 99 (2003) nr 2, s. 256-284; tenże, La sorte degli esposti dell'Ospedale di Santo Spirito di Roma nel '700 , „Ricerche di storia sociale e religiosa", 36 (2007) nr 72, s. 7-43; tenże, Il Conservatorio di Santo Spirito di Roma nei secoli XVII-XVIII, „Ricerche di storia sociale e religiosa”, 38 (2009) nr 75, s. 21-42.

${ }^{5}$ Surdacki, Dzieci porzucone w Szpitalu, s. 106-107, 129, 133-135.

${ }^{6}$ Tamże, s. 112-113, 117, 153-162. 
z nich pozostawało w szkole (jednocześnie było ich ok. 35-50). Inaczej działo się z dziewczętami, których znaczna liczba pozostawała w conservatorio na dłużej, czasami aż do końca życia. Liczba pensjonariuszek zamieszkujących w przytułku w XVII i XVIII w. oscylowała z reguły w granicach od 400 do $700^{7}$.

Zarząd nad conservatorio sprawowała zawsze przełożona. Początkowo była nią jedna z sióstr duchaczek, od końca zaś XVII w. kobieta świecka. Życie mieszkanek conservatorio poddane było pod bardzo surową klauzurę. Ich egzystencja i wychowanie kształtowane były w duchu i stylu klasztornym. Wyrażało się nie tylko w klauzurze ale i w noszonym stroju i intensywnych praktykach religijnych. Wiele z pensjonariuszek wstępowało zresztą do zakonu. Edukacja pensjonariuszy realizowana była poprzez rozwój życia religijnego oraz aktywną pracę na rzecz całego szpitala. Obowiązek codziennej pracy dotyczył wszystkich pensjonariuszek, z wyjątkiem chorych i starych kobiet ${ }^{8}$.

Jednym z najważniejszych celów, jakie stawiały przed sobą władze szpitalne było umożliwienie wychowankom asymilacji w społeczeństwie. Najczęściej ten cel realizowano poprzez powierzanie dziewcząt na służbę (a tempo nubile), a chłopców, jak już wspomniano - na naukę zawodu (ad artem).Najskuteczniejszą formą asymilacji społecznej było jednak wydawanie dziewcząt szpitalnych za mąż. Wychowanki wychodziły za mąż bezpośrednio z przytułku lub znajdowały mężów przebywając na służbie u opiekunów. Wszystkie podopieczne na wypadek zamążpójścia czy wstąpienia do zakonu otrzymywały ze strony szpitala 100 skudów posagu?.

W przeciwieństwie do brefotrofium, w dotychczasowych badaniach brak jest nie tylko szczegółowych studiów ale i przyczynkarskich artykułów naukowych, poświęconych infirmerii szpitala Św. Ducha w Rzymie. Trudno to zrozumieć, ponieważ swoje skromne opracowania mają nawet nieliczne szpitale - lecznice polskie: bonifratrów w Krakowie, Gdańsku czy Toruniu ${ }^{10}$. Wypełnienie tej ,pustki" badawczej staje się więc zadaniem palącym i fundamentalnym ze względów naukowych, społecznych i cywilizacyjno-humanitarnych. Szpital Św. Ducha - znajdujący się w „centrum chrześcijaństwa oraz europejskiego miłosierdzia” i miejscu studiów setek duchownych i naukowców z całego świata, nie znalazł jednak wśród nich prawdziwego historiografa. Być może zabrakło rodzimych badaczy zakonnych. Również fundator zakonu Guidon, jako jedyny z fundatorów słynnych zgromadzeń zakonnych, nie doczekał się nawet beatyfikacji, podczas gdy inni założyciele i twórcy dzieł dobroczynnych miano świętości zyskali niedługo po swej śmierci (św. Wincenty Paulo, św. Jan Boży, Kamil de Lellis, Filip Neri). Przyczyną niechęci do podejmowania tej problematyki, wydaje się ogrom zachowanych materiałów archiwalnych. Jak twierdzili historycy włoscy ,dopiero

${ }^{7}$ Tamże, s. 225-237, 335-337

${ }^{8}$ Tamże, s. 291-312.

${ }^{9}$ Tamże, s. 251-396.

${ }^{10}$ H. Komaryńska, Szpital Bonifratrów w Krakowie w XVII-XVIII wieku, Lublin 2010; K. Pękacka-Falkowska, Toruńska medycyna i farmacja wobec powietrza morowego $w$ świetle niemieckojęzycznego starodruku medycznego z 1709 roku, „Klio”, 11 (2008), s. 53-88; A. Szarszewski, Lekarzy czujne oczy. Medykalizacja w Gdańsku doby oświecenia, „Klio”, 15 (2010) s. 59-93. 
polski badacz podjął się opracowania tak ważnego dla powszechnej historii i kultury zagadnienia" (prof. Gabriele De Rosa) ${ }^{11}$. Obecnie zadanie to zamierzam po dłuższej przerwie zrealizować, odnośnie do w ogóle niezbadanej infirmerycznej części szpitala. Doprowadzi to do powstania pierwszego całościowego studium instytucji ważnej dla ogólnoeuropejskiej kultury.

W polskiej literaturze naukowej brak jest opracowań naukowych poświęconych infirmerycznej funkcji Szpitala Św. Ducha w Rzymie, jej działalność pozostaje w naszym kraju w zasadzie nieznana, za wyjątkiem ogólnych wzmianek w artykułach Klary Antosiewicz ${ }^{12}$. Informacje o infirmerii szpitala rzymskiego $\mathrm{w}$ naszym kraju upowszechniał jedynie piszący te słowa ${ }^{13}$. Z krajowych opracowań dla celów komparatystycznych przydatne moga być publikacje A. Szarszewskiego, T. Srogosza, K. Korpalskiej, H. Komaryńskiej ${ }^{14}$ oraz prace z historii medycyny: W. Szumowskiego, B. Seydy, W. Noszczyka ${ }^{15} \mathrm{i}$ inne.

Historia szpitalnictwa, zwłaszcza jego infirmerycznej funkcji, nie należała do wiodących nurtów badawczych w powszechnych badaniach historycznych. Szpitalowi Św. Ducha poświęcano sporo miejsca w pracach ogólnych. Historycznoźródłowy wymiar mają dzieła napisane w XVII w. przez C. Fanucciego i C.B. Piazzę, a także monumentalne studium kard. C.L. Morichiniego z połowy XIX w. ${ }^{16}$ Niezastąpionym do dzisiaj dziełem jest synteza dobroczynności rzymskiej pod red. V. Monachino ${ }^{17}$, z fragmentami odnoszącymi się do Szpitala Św. Ducha. $Z$ nowszych opracowań wartościowa jest praca M. Piccialutti ${ }^{18}$. Duży dorobek dotyczący Szpitala Św. Ducha w Rzymie mają dyrektorzy Biblioteki Lancisiana

${ }^{11}$ Surdacki, Il brefotrofio, s. 7-8.

${ }^{12}$ K. Antosiewicz, Opieka nad chorymi i biednymi w krakowskim Szpitalu Świętego Ducha (1220-1741), „Roczniki Humanistyczne”, 26 (1978) z. 2, s. 35-79; taż, Zakon Ducha Świętego w Polsce średniowiecznej, „Nasza Przeszłość”, 23 (1966) s. 167-198.

${ }^{13}$ Np. M. Surdacki M., Dzieci porzucone w Szpitalu Świętego Ducha w Rzymie w XVIII wieku, Lublin 1998.

${ }^{14}$ A. Szarszewski, Lekarzy Lekarzy czujne oczy. Medykalizacja w Gdańsku doby oświecenia, „Klio”, 15 (2010) s. 59-93; T. Srogosz, Problemy, sanitarno-zdrowotne w dziatalności administracji Rzeczypospolitej w okresie stanisławowskim, Łódź 1993; W.K. Korpalska, Sześć wieków opieki zdrowotnej w Bydgoszczy, Toruń 2008; H. Komaryńska, Szpital Bonifratrów w Krakowie w XVII-XVIII wieku, Lublin 2010.

${ }^{15}$ W. Szumowski, Historia medycyny filozoficznie ujęta, Warszawa 1935; B. Seyda, Dzieje medycyny w zarysie, Warszawa 1973; W. Noszczyk, Zarys dziejów medycyny w Polsce, t. 1-3, Warszawa 2016.

${ }^{16}$ C. Fanucci, Trattato di tutte le opere pie dell'alma città di Roma, Roma 1601; C.B. Piazza, Opere pie di Roma, descritte secondo lo statopresente e dedicate alla Santità di N.S. Innocenzo XI dall'abbate Carlo Bartolomeo Piazza degli Oblati di Milano, Roma 1679; C.L. Morichini, Degl'istituti di pubblica carità e di istruzione primaria in Roma, Roma 1835; tenże, Degl'istituti di pubblica carità ed istruzione primaria e delle prigioni in Roma, Roma 1842.

${ }^{17}$ La carità cristiana in Roma, a cura di V. Monachino, Bologna 1968.

${ }^{18} \mathrm{M}$. Piccialuti,La carità come metodo di governo. Istituzioni caritative a Roma da pontificato di Innocenzo III a quello di Benedetto XIV, Torino 1994. 
A. Canezza i P. De Angelis ${ }^{19}$. Publikacje, zwłaszcza drugiego autora, zawierają nieudokumentowaną faktografię oraz niewiadomego pochodzenia przedruki źródłowe. Aspektami służby medycznej zajmował się P. Savio oraz I. Pappalardo ${ }^{20}$. Oprócz wymienionych autorów drobnymi aspektami życia szpitala duchackiego w Rzymie zajmowali się P.B. De Altari, R. Grègoire, M. Comforti ${ }^{21}$. Warto wspomnieć jeszcze szkice A. Palmy, służące jako przewodniki czy informatory ${ }^{22}$.

Najobszerniejszy zbiór materiałów prezentujących różne aspekty funkcjonowania Szpitala Św. Ducha zawiera tom referatów z międzynarodowej konferencji w Rzymie (15-17 maja 2001 r.) poświęconej 800 -letniej rocznicy fundacji szpitala (uczestniczył w niej M.S.). Godny uwagi jest też artykuł Anny Esposito dotyczacy opieki sanitarnej w szpitalu oraz syntezy historii medycyny włoskiej (G. Cosmacini, S. De Rienzi, E. Brambilla) ${ }^{23}$. Z badaczy spoza Włoch studia nad szpitalem Św. Ducha prowadzą Eunice D. Howe (USA) i Gisela Drossbach z Augsburga ${ }^{24}$. Generalnie, pomimo dużej liczby publikacji, infirmeria Szpitala Św. Ducha nie posiada do dzisiaj nowoczesnej monografii, opartej na systematycznych badaniach źródłowych.

Autorami ważniejszych prac przeglądowych z historii szpitalnictwa w Europie Zachodniej w XVII-XVIII wieku anglo- i niemieckojęzycznych są: Dieter Jetter, Axel Hinrich Murken, Hans-Peter Rhomberg, Edward Chaney, Colin Jones, Martin Scheutz ${ }^{25}$. O największych szpitalach pisali: w Berlinie - Johanna Bleker,

${ }^{19}$ P. De Angelis, Insegnamento della Medicina negli Ospedali di Roma, Roma 1948; tenże, Arcispedale di Santo Spirito in Saxia nel pasato e nel presente, Roma 1952; A. Canezza, M. Casalini, Il Pio istituto di S. Spirito e ospedali Riuniti di Roma, Roma 1933; tenże, Gli arcispedali di Roma nella vita cittadina nella storia e nell'arte, Roma 1933.

20 P. Savio, Ricerche sui medici e chirurghi dell'ospedale di Santo Spirito in Sassia (secc. XVI-XVIII), „Archivio della Società Romana di Storia Patria”, XCIV (XXV della serie III), 1971, s. 18-42I; I. Pappalardo, Litotomi e oculisti Preciani e Norcini-Soppressione nell'ospedale di Santo Spirito nel 1751, Roma 1963.

${ }^{21}$ P.B. Da Altari, L'ospedale romano di S. Spirito in Sassia e i Cappucini. Note storico-commemorative del I centenario dell'assistenza spirituale affidata ai cappucini 1856-1956, Roma 1956; R. Gregoire, Servizio dell'anima quando del corpo nell'ospedale di Santo Spirito, „Ricerche per la Storia Religiosa di Roma", 3 (1979) s. 221-254; M. Conforti, The Biblioteca Lancisiana and the 1714 edition of Eustachi's anatomical plates, or Ancients and Moderns reconciliated, in: Conflicting duties, science, medicine and religion in Rome, 1550-1750, edited by Maria Pia Donato and Jill Kraye, London, Warburg Institute, 2009, p. 323-330.

${ }^{22}$ A. Palma, L'ospedale di Santo Spirito in Saxia, Roma 1994.

${ }^{23}$ G. Cosmacini, La medicina dei papi, Bari, Roma 2018; tenże, Storia della medicina e della sanità in Italia. Dalla peste europea alla guerra mondiale. 1348-1918, Bari 1994; S. De Renzi, Storia della medicina italiana, Bologna 1966; B. Brambilla, La medicina nel Settecento: dal monopolio dogmatico alla professione scientifica, in Storia d'Italia, Annali 7, Malattia e medicina, a cura di Franco Della Peruta, Torino 1984.

${ }^{24}$ Eunice D. Howe, Art and culture at the Sistine court: Palatina's Life of SixtusIV and the frescoes of the Hospital of Santo Spirito, Roma 2005; Drossbach G. Christliche caritas als Rechtsinstitut: Hospital und Orden von Santo Spirito in Sassia (1198-1378) (Kirchen- und Staatskirchenrecht 2), Paderborn 2005.

${ }^{25}$ Jetter D., Das europäische Hospital. Von der Spätantike bis 1800, Köln 1986; A.H. Murken, Vom Armenhospital zum Großklinikum. Die Geschichte des Krankenhauses vom 18. Jahrhundert 
Volker Hess, Ernst Peter Fischer, Georg Harig ${ }^{26}$, w Paryżu - Guenter B. Risse ${ }^{27}$, w Londynie - James O. Robinson ${ }^{28}$, o szpitalach holenderskich - Ronald Sluijter ${ }^{29}$. O wiedeńskich - Bernhard Grois, Paul Pfeiffer ${ }^{30}$. Poczesne miejsce zajmują dzieła Michela Foucaulta ${ }^{31}$, które ukazują zmiany instytucjonalne i ideowe w szpitalnictwie między XVII a XVIII wiekiem.

W Szpitalu Świętego Ducha jako instytucji leczniczej istniało kilka agend o profilu edukacyjno-oświatowym, mających na celu przygotowanie i szerzenie wiedzy i kultury medycznej, a także kształcenie przyszłych lekarzy i chirurgów. Chodzi o bibliotekę i akademię medyczną, które ufundował lekarz papieski - Giovanni Maria Lancisi (1654-1720). Biblioteka Lancisiana, powstała w 1714 r., została przeznaczona dla studentów medycyny. Z kolei Accademia Lancisiana, założona w 1720 r., stanowiąca towarzystwo naukowe skupiające wybitnych lekarzy i chirurgów, była miejscem konferencji i odczytów, propagujących odkrycia i wyniki badań medycznych. Odbywały się tam publiczne konkursy na stanowska lekarzy i chirurgów szpitalnych. W szpitalu istniał też teatr i muzeum anatomiczne, obie instytucje złożone w 1772 r. Zadaniem teatru było organizowanie publicznych pokazów anatomicznych. Muzeum natomiast miało gromadzić eksponaty anatomiczne, służące do nauki studentom i przyszłym chirurgom. Ważną funkcję pełniła znakomicie zaopatrzona apteka (Spezieria), zaopatrująca chorych z całego szpitala, również przytułku. Należy też wspomnieć o wewnętrznym szpitaliku, w którym leczono chorych należących do służby i personelu szpitalnego (Ospedale della Famiglia) oraz agregowanym szpitaliku dla upośledzonych umysłowo (per i pazzi).

Szpital Św. Ducha był lecznicą wielooddziałową i wielofunkcyjną, przystosowaną do kuracji różnorodnych chorób, co wtedy było zjawiskiem wyjątkowym. Znajdowało się w nim sześć oddziałów: dla gorączkujących, rannych, chorych na

bis zur Gegenwart,3. Auflage, Köln 1995; H.P. Rhomberg, Das Hospital. Heil- und Pflegestätten im Wandel der Zeit, Lindenberg im Allgäu 2015; E. Chaney, Philanthropy in Italy: English Observations on Italian Hospitals 1545-1789, w: The Evolution of the Grand Tour: Anglo-Italian Cultural Relations since the Renaissance, 2nd ed., London 1998; C. Jones, The Charitable Imperative: Hospitals and Nursing in Ancient Regime and Revolutionary France, London 1999; M. Scheutz et al. (red.), Hospitals and Institutional Care in Medieval and Early Modern Europe, London 2009;

${ }^{26}$ E.P. Fischer, Die Charité: Ein Krankenhaus in Berlin - 1710 bis heute, Berlin 2010; G. Harig, Ärzte und Patienten der Charité im 18. Jahrhundert, w: Miniaturen zur Geschichte, Kultur und Denkmalpflege Berlins, 18 (1985) s. 26-36.

${ }^{27}$ G.B. Risse, Mending bodies, Saving Souls: A History of Hospitals, New York 2009.

${ }^{28}$ J.O. Robinson, The Royal and Ancient Hospital of St Bartholomew (Founded 1123), "Journal of Medical Biography", 1999, vol 1 (1): 23-30.

${ }^{29}$ E. Sluijter, Oud, afgesloofd, behoeftig en arm. Bejaardenzorg in Leiden in de achttiende eeuw., Doctoraalscriptie Universiteit Leiden, 1995.

${ }^{30}$ B. Grois, Das Allgemeine Krankenhaus in Wien und seine Geschichte, Mit einem Geleitwort von Erna Lesky, Wien 1965; P. Pfeiffer, Das Allgemeine Krankenhaus in Wien von 1784: vor dem Hintergrund der Geschichte des Hospitalwesens und der theresianisch-josephinischen Gesundheitsund Fürsorgepolitik im 18. Jahrhundert, Munster 2012.

${ }^{31}$ M. Foucault, Historia szaleństwa $w$ dobie klasycyzmu, Warszawa 1987; tenże, Narodziny kliniki, Warszawa 2009. 
gruźlicę, dotkniętych szkorbutem, chorych na kamienie oraz dotkniętych świerzbem.

Pod względem chronologicznym badania objęłyby zasadniczo XVIII stulecie, które w perspektywie europejskiej można nazwać „wiekiem oświecenia”. Za wyborem tego okresu przemawiają względy merytoryczne (wyraźny postęp w badaniach empirycznych, medycznych) i formalne (nawiązanie do mojej książki o przytułku dla podrzutków), w tym podstawa źródłowa, najbogatsza dla XVIII stulecia. Duże znaczenie posiadały też reformy ustrojowe z drugiej połowy XVII w., które zaowocowały dopiero w następnym stuleciu. Górną granicę stanowić będzie koniec XVIII w. i zbiegające się z nim powstanie republiki rzymskiej i panowanie Napoleona w Państwie Kościelnym. Czasy te przyniosły istotne zmiany w sposobie administrowania szpitalem i przyczyniły się do niechybnego upadku Zakonu Świętego Ducha, sprawującego dotychczas rządy nad szpitalem. Badania kończą się okresem, który miał bardzo duże znaczenie w procesie stopniowego przechodzenia od modelu państwa wyznaniowego do oddzielenia Kościoła od państwa.

Koniec XVIII w. stanowi wyraźną cezurę w rozwoju szpitalnictwa w Europie, bowiem odtąd rozpoczął się proces upaństwawiania szpitali i przekształcania ich z przytułków w lecznice. Kształtowało się wtedy pojęcie państwowej opieki społecznej. Wiek XVIII daje możliwość obserwowania rozwoju sztuki medycznej i przechodzenia od tradycyjnych form leczenia do nowoczesnego szpitala, w którym zaczęto praktykować naukowe postulaty XVII-wiecznych filozofów i lekarzy (Leibnitz). Dla celów porównawczych i wyjaśnienia przyczyn lub następstw badanych zjawisk często będzie się sięgać do archiwaliów XVII i XIX-wiecznych.

Badania mają wykazać w jakim stopniu infirmeria rzymska, stosująca innowacyjne i prekursorskie rozwiązania w leczeniu chorych, miała inspiracyjny i modelowy wpływ na rozwój medycyny i kształtowanie się nowoczesnego szpitala europejskiego. Mają też ukazać edukacyjną rolę tej znakomicie wyposażonej „akademii i kliniki medycznej” w kształceniu lekarzy i służby medycznej. Badania te zahaczają o historię medycyny lecz główny nacisk powinien być położony na wymiar społeczny instytucji, na jej ,zbiorowisko” ludzkie - pensjonariuszy. Ważne będzie ukazanie rozwoju medycyny i lecznictwa, procesu medykalizacji i odpowiedź na pytanie na ile infirmeria Sw. Ducha odgrywała przodującą rolę na tle innych szpitali leczniczych Rzymu i Europy. Istotne będzie przedstawienie struktury wewnętrznej, wyposażenia infirmerii, sposobów leczenia, stosowanych medykamentów oraz analizy dotyczące etiologii chorób. Funkcjonowanie szpitala - infirmerii należy przedstawić w szerszym kontekście społecznym, kościelnym i cywilnym.

Byłyby to nowatorskie badania, umożliwiające porównanie stanu rozwoju medycyny i lecznictwa w wielkich miastach Europy. Informacje archiwalne i wnioski ukazane zostaną w kontekście procesów zachodzących w innych krajach europejskich i istniejących tam ważnych szpitalach. Takimi w 2. połowie XVIII w. były szpitale wiedeńskie, w których kształtował się nowy standard kliniczny. Istotny wkład w rozwój szpitalnictwa w XVIII wieku wniósł szpital Charite 
w Berlinie. To tam określano w XVIII w. nowe przepisy relacji lekarz-pacjent ${ }^{32}$. Innymi ważnymi szpitalami wczesnej nowożytności są Hotel Dieu w Paryżu, Bedlam Hospital w Londynie i szpitale holenderskie, które od XVII w. wyznaczały nowe standardy w traktowaniu obłąkanych, leczeniu chorych czy badaniach (proto-klinicznych) ${ }^{33}$.

Podstawowe materiały źródłowe dotyczące Szpitala Św. Ducha, liczące ponad 3.000 teczek, przechowywane są w Archivio do Stato di Roma. Niespotykane bogactwo i różnorodność archiwaliów powodują konieczność ich trafnego doboru i selekcji, a nawet sondażu i kierowania się intuicją. Najbardziej intrygującym zadaniem badawczym będą kompleksowe analizy ogromnego zbioru hospitalizowanych, którzy podobnie jak rzesze podrzutków szpitalnych, tworzyli łącznie swego rodzaju odrębny stan społeczny.

O znaczeniu problemu opieki nad chorymi świadczy nieprzerwana debata społeczna (także parlamentarna i medialna) w poszczególnych państwach, dotycząca systemów opieki szpitalno-medycznej. Dlatego poznanie form rozwoju sztuki leczniczej i ewolucji szpitala od średniowiecznego hospicjum do nowoczesnej placówki - kliniki medycznej, stanowi bardzo ważne wyzwanie naukowe z punktu widzenia ogólnej wiedzy o kulturze Europy. Opracowanie bardzo ważnej w rozwoju medycyny i lecznictwa, placówki rzymskiej wzbogaci historiografię powszechną, będzie miało wymiar uniwersalny. Wzbogaci historię społeczną (Annales), historię Kościoła, historię zakonów i papiestwa, historię medycyny, ogólnie historię powszechną, da asumpt do dalszych analogicznych badań nad szpitalami europejskimi, powiększy wkład polskich badań w historiografię światową. Wyniki badań pozwolą spojrzeć na badany problem w sposób ambiwalentny, z jednej strony dostrzec dzisiejszy postęp w poziomie opieki, wiedzy medycznej czy medykalizacji, z drugiej zaś wykazać, jak „nowoczesna” na owe czasy już była infirmeria Ś. Ducha w Rzymie. Badania porównawcze ukażą też, na ile w minionych wiekach w dziedzinie medycyny Rzeczpospolita odstawała od Zachodu.

Powstanie monografii infirmerii Szpitala Św. Ducha będzie pionierskim osiągnięciem, a szpital doczeka się integralnego - dwuczęściowego opracowania dwu odrębnych instytucji, znajdujących się w tym samym kompleksie budowlanym. Badania mają ukazać infirmerię Św. Ducha w kontekście przemian modelu opieki medycznej i społecznej na tle ,rewolucji” naukowych XVII i XVIIII w. i zachodzących przemian w Europie przełomu XVIII i XIX w. Wykorzystując teorię i koncepcję społecznej historii medycyny, obligującą do stawiania pytań badawczych, hipotez i wyciągania wniosków, nadamy badaniom ujęcie nowatorskie, a nie tylko opisowe. Znajdzie tu zastosowanie „koncepcja czynników egzogennych" ukazująca ich wpływ na co działo się wewnątrz szpitala np. fluktuację liczby chorych w szpitalu. Takie podejście pozwoli sformułować pytania i określić cele badawcze, takie jak:

\footnotetext{
${ }^{32}$ Zob. przypis 26 .

${ }^{33}$ Zob. przypis 25.
} 
- Struktura infirmerii: oddziały dla chorych: Sala Sistina, Nuovo Braccio, szpitalik Św. Filipa, Accademia i Biblioteca Lancisiana, Teatro Anatomico, apteka, klasztor żeński i męski, kościoły i kaplice dla chorych.

- Zarząd i personel: nadzór papieży, kanonicy regularni Św. Ducha, służba usługowa, spowiednicy (kapucyni, bernardyni), personel świecki.

- Rola papieży w życiu szpitala, wydawanie dekretów normatywnych, wizytowanie szpitala

- Pensjonariusze szpitalni: liczby chorych, rodzaje - etiologia chorób, wiek, płeć, wyznanie, pochodzenie społeczne i geograficzne, przyczyny zgonów, ruch chorych, długość pobytu, testamenty, przepływ pacjentów między szpitalami rzymskimi, epidemie ubiór

- Życie codzienne: obowiązki i praktyki religijne, rozkład dnia, żywienie,

- Związek infirmerii z Conserwatorio (przytułek dla porzuconych dziewcząt) i Scuola dei Putti (szkoła dla porzuconych chłopców).

- Zaplecze medyczno-lekarskie, lekarze, chirurdzy, personel pielęgniarski

- Funkcja edukacyjna szpitala, konkursy na stanowiska lekarsko-chirurgiczne, pokazy anatomiczne, szpital jako akademia medyczna.

W kontekście planowanych badań pojawiają się też pytania, hipotezy i problemy badawcze, takie jak: kuracji

* Zmiany w sposobie leczenia - od medycyny tradycyjnej do nowoczesnej

* Diagnozowanie i odróżnianie chorób

* Rodzaje i źródła społeczne epidemii

* Przytułek czy klinika, „Umieralnia” czy prawdziwa lecznica

* Instytucja lecznicza-medyczna czy edukacyjno-naukowa (sekcje zwłok, eksperymenty)

* Wybitni lekarze G. Baglivi, G.M. Lancisi, a szpital duchaków

* Związki szpitala z wydziałem medycznym Sapienza?

* Typologia chorób, profilaktyka zdrowotna

* Status chirurga i lekarza

* Standardy relacji lekarz - pacjent

* Etatowość i rekrutacja personelu medycznego

* Egalitaryzm społeczny czy różnicowanie pacjentów

* Szpital papieski a prądy i „nowości” oświeceniowe

* Dualizm władzy papieskiej (kościelnej i państwowej) nad szpitalem

* Kościelna instytucja dobroczynna czy nowoczesna klinika państwowa

* Szpital wyznaniowy czy otwarty

* Rola laikatu w służbie życiu szpitala (Bractwo Św. Ducha)

* Duszpasterstwo czy leczenie

* Obłęd i szaleństwo - choroba czy przekleństwo. 


\section{BIBLIOGRAFIA}

Antosiewicz K., Opieka nad chorymi i biednymi w krakowskim Szpitalu Świętego Ducha (1220-1741), „Roczniki Humanistyczne”, 26 (1978) z. 2, s. 35-79.

Antosiewicz K., Zakon Ducha Świętego w Polsce średniowiecznej, „Nasza Przeszłość”, 23 (1966) s. 167-198.

Bleker J., Hess V. (red.): Die Charité. Geschichte(n) eines Krankenhauses. Akademie-Verlag, Berlin 2010.

Brambilla B., La medicina nel Settecento: dal monopolio dogmatico alla professione scientifica, in Storia d'Italia, Annali 7, Malattia e medicina, a cura di Franco Della Peruta, Torino 1984.

Canezza A., Casalini M., Il Pio istituto di S. Spirito e ospedali Riuniti di Roma, Roma 1933.

Canezza A., Gli arcispedali di Roma nella vita cittadina nella storia e nell'arte, Roma 1933.

Chaney E., Philanthropy in Italy: English Observations on Italian Hospitals 1545-1789, w: The Evolution of the Grand Tour: Anglo-Italian Cultural Relations since the Renaissance, 2nd ed., London 1998.

Jones C., The Charitable Imperative: Hospitals and Nursing in Ancient Regime and Revolutionary France, London 1999.

Conforti M., The Biblioteca Lancisiana and the 1714 edition of Eustachi's anatomical plates, or Ancients and Moderns reconciliated, in Conflicting duties, science, medicine and religion in Rome, 1550-1750, edited by Maria Pia Donato and Jill Kraye, London, Warburg Institute, 2009, p. 323-330.

Cosmacini G., La medicina dei papi, Bari-Roma 2018.

Cosmacini G., Storia della medicina e della sanità in Italia. Dalla peste europea alla guerra mondiale. 1348-1918, Bari 1994.

Da Altari P.B., L'ospedale romano di S. Spirito in Sassia e i Cappucini. Note storicocommemorative del I centenario dell'assistenza spirituale affidata ai cappucini 18561956, Roma 1956.

De Angelis P., Arcispedale di Santo Spirito in Saxia nel pasato e nel presente, Roma 1952.

De Renzi S., Storia della medicina italiana, Bologna 1966.

Drossbach G. Christliche caritas als Rechtsinstitut: Hospital und Orden von Santo Spirito in Sassia (1198-1378) (Kirchen- und Staatskirchenrecht 2), Paderborn 2005.

Fanucci C., Trattato di tutte le opere pie dell'alma città di Roma, Roma 1601.

Fischer E.P., Die Charité: Ein Krankenhaus in Berlin - 1710 bis heute, Berlin 2010.

Focuault M., Historia szaleństwa w dobie klasycyzmu, Warszawa 1987.

Foucault M., Narodziny kliniki, Warszawa 2009.

Eunice D. Howe, Art and culture at the Sistine court: Palatina's Life of SixtusIV and the frescoes of the Hospital of Santo Spirito, Roma 2005.

Gregoire R., Servizio dell'anima quando del corpo nell'ospedale di Santo Spirito, „Ricerche per la Storia Religiosa di Roma", 3 (1979) s. 221-254.

Grois B., Das Allgemeine Krankenhaus in Wien und seine Geschichte, Mit einem Geleitwort von Erna Lesky, Wien 1965; Innsbruck/Wien/Bozen 2010.

Harig G., Arzte und Patienten der Charité im 18. Jahrhundert, w: Miniaturen zur Geschichte, Kultur und Denkmalpflege Berlins, 18 (1985) s. 26-36.

Jetter D., Das europäische Hospital. Von der Spätantike bis 1800, Köln 1986.

Komaryńska H., Szpital Bonifratrów w Krakowie w XBVII-XVIII wieku, Lublin 2010.

Korpalska W. K., Sześć wieków opieki zdrowotnej w Bydgoszczy, Toruń 2008. 
La carità cristiana in Roma, a cura di V. Monachino, Bologna 1968.

Morichini C.L., Degl'istituti di pubblica carità e di istruzione primaria in Roma, Roma 1835.

Morichini C.L., Deg'istituti di pubblica carità ed istruzione primaria e delle prigioni in Roma, Roma 1842.

Murken A.H., Vom Armenhospital zum Großklinikum. Die Geschichte des Krankenhauses vom 18. Jahrhundert bis zur Gegenwart, 3. Auflage, Köln 1995.

Noszczyk W., Zarys dziejów medycyny w Polsce, t. 1-3, Warszawa 2016.

Pappalardo I., Litotomi e oculisti Preciani e Norcini-Soppressione nell'ospedale di Santo Spirito nel 1751, Roma 1963.

Pazzini A., La medicina nella storia, nell'arte,nel costume, Milano 1963.

Pfeiffer P., Das Allgemeine Krankenhaus in Wien von 1784: vor dem Hintergrund der Geschichte des Hospitalwesens und der theresianisch-josephinischen Gesundheits- und Fürsorgepolitik im 18. Jahrhundert, Munster 2012.

Piazza C.B., Opere pie di Roma, descritte secondo lo statopresente e dedicate alla Santità di N.S. Innocenzo XI dall'abbate Carlo Bartolomeo Piazza degli Oblati di Milano, Roma 1679.

Pękacka-Falkowska K., Toruńska medycyna i farmacja wobec powietrza morowego $w$ świetle niemieckojęzycznego starodruku medycznego z 1709 roku, „Klio”, 11 (2008) s. 53-88.

Rhomberg H.P., Das Hospital. Heil- und Pflegestätten im Wandel der Zeit, Lindenberg im Allgäu 2015.

Piccialuti M.,La carità come metodo di governo. Istituzioni caritative a Roma da pontificato di Innocenzo III a quello di Benedetto XIV, Torino 1994.

Risse G.B., Mending bodies, Saving Souls: A History of Hospitals, New York 2009.

Robinson J.O, The Royal and Ancient Hospital of St Bartholomew (Founded 1123), "Journal of Medical Biography", 1999, vol 1 (1): 23-30.

Savio P., Ricerche sui medici e chirurghi dell'ospedale di Santo Spirito in Sassia (secc. $X V I-X V I I I)$, „Archivio della Società Romana di Storia Patria”, XCIV (XXV della serie III), 1971, s. 18-42.

Scheutz M. et al. (red.), Hospitals and Institutional Care in Medieval and Early Modern Europe, London 2009.

Sluijter R., Oud, afgesloofd, behoeftig en arm. Bejaardenzorg in Leiden in de achttiende eeuw., Doctoraalscriptie Universiteit Leiden, 1995.

Srogosz T., Problemy, sanitarno-zdrowotne w działalności administracji Rzeczypospolitej w okresie stanisławowskim, Łódź 1993.

Surdacki M., Dzieci porzucone w Rzymie i okolicach w XVIII wieku, „Roczniki Nauk Społecznych", 22 (1994) z. 2, s. 84-108.

Surdacki M., Dzieci porzucone w Szpitalu Świętego Ducha w Rzymie w XVIII wieku, Lublin 1998.

Surdacki M., „,Figli legitimi” w Rzymie i Państwie Kościelnym w XVIII w. „Roczniki Nauk Społecznych", 23 (1995) z. 2, s. 87-100.

Surdacki M., Il brefotrofio dell'Ospedale di Santo Spirito in Roma nel XVIII secolo, Conferenze 115, Varsavia-Roma 2002.

Surdacki M., Losy wychowanków Szpitala Świętego Ducha w Rzymie w XVIII wieku, „Roczniki Nauk Społecznych”, 25 (1997) s. 141-168.

Surdacki M., Matżeństwa wychowanek Szpitala Świętego Ducha w Rzymie w XVII-XVIII wieku, „Kwartalnik Historii Kultury Materialnej”, 1996, nr 2, s. 137-156.

Surdacki M., Życie religijne podopiecznych Szpitala Świętego Ducha w Rzymie w XVII $i$ XVIII wieku, „Roczniki Nauk Społecznych”, 24 (1996) z. 2, s. 315-333. 
Surdacki M., Marriages of Wards of Rome's Holy Spirit Hospital in the $17^{\text {th }}$ and $18^{\text {th }}$ centuries, „Acta Poloniae Historica”, 79 (1999) s. 99-122

Surdacki M., La vita religiosa nel „Conservatorio” dell'ospedale di Santo Spirito in Roma, nei secoli XVII-XVIII, „Ricerche di storia sociale e religiosa”, 27 (1998) nr 54, s. 149-165.

Surdacki M., L'abbandono dei bambini a Roma e dintorni nel secolo XVIII, „Archivio della Società romana di storia patria", 123 (2000) s. 169-199.

Surdacki M., I trovatelli nelle famiglie affidatarie a Roma e nei dintorni nel Settecento, „Ricerche di storia sociale e religiosa”, 30 (2001) nr 59, s. 91-120.

Surdacki M., Il "Conservatorio" e la "Scuola dei putti" nell'Ospedale di Santo Spirito di Roma nei secoli XVII-XVIII, Atti del convegno internazionale sull'antico ospedale di Santo Spirito di Roma, „Il Veletro. Rivista della Civiltà Italiana”, 45 (2001) nr 5-6, s. 253-267.

Surdacki M., Le condizioni fisiche degli ospiti del brefotrofio di Santo Spirito in Roma nel XVIII secolo, „Medicina nei secoli”, 14 (2002) nr 1, s. 111-134.

Surdacki M., Le nutrici a Roma e nello Stato pontificio nei secoli XVII-XVIII, „Archivio della Società romana di storia patria”, 125 (2002) s. 105-126.

Surdacki M., La scuola per i maschi nell'Ospedale di Santo Spirito di Roma nei secoli XVII-XVIII., „Studium”, 99 (2003) nr 2, s. 256-284.

Surdacki M., La sorte degli esposti dell'Ospedale di Santo Spirito di Roma nel '700 , „Ricerche di storia sociale e religiosa", 36 (2007) $\mathrm{nr} 72$, s. 7-43.

Surdacki M., Il Conservatorio di Santo Spirito di Roma nei secoli XVII-XVIII, „Ricerche di storia sociale e religiosa", 38 (2009) nr 75, s. 21-42.

Szarszewski A., Lekarzy czujne oczy. Medykalizacja w Gdańsku doby oświecenia, „Klio”, 15 (2010) s. 59-93.

Szumowski W., Historia medycyny filozoficznie ujęta, Warszawa 1935.

\section{INFIRMERIA ŚWIĘTEGO DUCHA W RZYMIE W XVII-XVIII WIEKU. PERSPEKTYWY BADAWCZE.}

\section{Streszczenie}

Szpital Świętego Ducha w Rzymie, ufundowany w 1198 r., przez papieża Innocentego III, a zarządzany przez szpitalny zakon Świętego Ducha, był największą placówką charytatywną w Europie w średniowieczu i czasach nowożytnych. Aż do zjednoczenia Włoch pełnił dwie funkcje: przytułku dla podrzutków (brefotrofium) oraz szpitala-lecznicy dla chorych (infirmeria). Funkcja opiekuńcza Szpitala Świętego Ducha, jako przytułku dla dzieci porzuconych, została już kompleksowo zbadana i opracowana przez piszącego te słowa (Dzieci porzucone w Szpitalu Świętego Ducha w Rzymie w XVIII wieku, Lublin 1998; Il brefotrofio dell'Ospedale di Santo Spirito in Roma nel XVIII secolo, Conferenze 115, Varsavia-Roma 2002). W przeciwieństwie do brefotrofium, w dotychczasowych badaniach bark jest nie tylko szczegółowych studiów ale i przyczynkarskich artykułów naukowych, poświęconych infirmerii szpitala Św. Ducha w Rzymie w jakimkolwiek okresie. Z tego względu warto pokusić się do opracowanie drugiej części szpitala rzymskiego, pełniącej funkcję lecznicy dla chorych. Takie badania zamierza podjąć autor tego artykułu. 
Szpital Świętego Ducha był lecznicą wielooddziałową i wielofunkcyjną, przystosowaną do kuracji różnorodnych chorób, co w wtedy było zjawiskiem wyjątkowym. Badania mają wykazać $w$ jakim stopniu infirmeria rzymska, stosująca innowacyjne i prekursorskie rozwiązania w leczeniu chorych, miała inspiracyjny i modelowy wpływ na rozwój medycyny i kształtowanie się nowoczesnego szpitala europejskiego. Powstanie monografii infirmerii szpitala Św. Ducha byłoby pionierskim osiągnięciem, a szpital doczeka się integralnego - dwuczęściowego opracowania dwu odrębnych instytucji, znajdujących się w tym samym kompleksie budowlanym. Badania mają ukazać infirmerię Św. Ducha w kontekście przemian modelu opieki medycznej i społecznej na tle „rewolucji” naukowych XVII i XVIIII w. i zachodzących przemian w Europie przełomu XVIII i XIX w.

Słowa kluczowe: infirmeria; szpital; Rzym; chorzy; medycyna; Zakon Świętego Ducha

\title{
THE HOLY SPIRIT INFIRMARY IN ROME IN THE 17TH-18TH CENTURIES - RESEARCH PROSPECTS
}

\begin{abstract}
Summary
The Holy Spirit Hospital in Rome, founded in 1198 by Pope Innocent III and managed by the Hospitallers of the Holy Spirit was the biggest charity in medieval and modern Europe. Until the unification of Italy, it had two functions: an orphanage for foundlings (brefotrofium) and a hospital for the ill (infirmary). The Holy Spirit Hospital as an orphanage for abandoned children has already been thoroughly studied by the author of this article (The Children Abandoned in the Holy Spirit Hospital in Rome in the 18th century, Lublin 1998; Il brefotrofio dell'Ospedale di Santo Spirito in Roma nel XVIII secolo, Conferenze 115, Varsavia-Roma 2002). The current literature lacks not only detailed studies but also contributory articles devoted to the Holy Spirit Infirmary in Rome in any period (contrary to brefotrofium). Therefore it is worth studying the other function of the Roman hospital, namely the infirmary for ill people. And the author of the following article intends to do this task.

The Holy Spirit Hospital was an infirmary with a number of wards and functions adapted for the treatment of various diseases, which was an exceptional phenomenon at the time. The aim of the research is to show to what extent the Roman infirmary, using innovative and pioneering treatments of the ill, influenced the development of medicine and the shape of the modern European hospital. The monograph about the Holy Spirit Hospital would be a pioneering achievement and the hospital would have an integral, twopart study of the two separate institutions functioning in the same buildings. The research intends to present the Holy Spirit Infirmary in the context of the changes in medical and social care against a background of the scientific 'revolutions' of the 17th and 18th centuries and changing Europe at the turn of the 19th century.
\end{abstract}

Keywords: an infirmary; a hospital; Rome; the ill; medicine; the Hospitallers of the Holy Spirit 